\title{
Precipitation of the Thyrotropin Receptor and Identification of Thyroid Autoantigens using Graves' Disease Immunoglobulins
}

Paula Heyma and Leonard C. Harrison

Department of Diabetes and Endocrinology, University of Melbourne, and Department of Medicine. The Royal Melbourne Hospital, Australia

bstract. The thyrotropin (TSH) receptor is a putative target for autoantibodies in Graves' hyperthyroidism and therefore, should be capable of being identified, isolated, and structurally characterized by immunological means. To this end, four sera from patients with hyperthyroidism, three of which inhibited the binding of ${ }^{125} \mathrm{I}-\mathrm{TSH}$ to Triton-solubilized human thyroid membranes, were used to isolate TSH receptors by immunoprecipitation. To account for an effect of TSH binding or receptor occupancy on the ability of Graves' immunoglobulins to precipitate TSH receptors, two approaches were taken: (a) specific ${ }^{125} \mathrm{I}-\mathrm{TSH}$ binding activity was measured after solubilized thyroid membranes had been incubated with Graves' sera followed by precipitation with Staphylococcus protein A ("receptor depletion"); (b) TSH binding sites were labeled with ${ }^{125} \mathrm{I}$-TSH and the complexes were precipitated using Graves' sera and Staphylococcus protein A ("receptor precipitation").

The three sera which inhibited ${ }^{125} \mathrm{I}$-TSH binding depleted ${ }^{125} \mathrm{I}$-TSH binding activity between $30-80 \%$. Preformed complexes between Staphylococcus protein $A$ and immunoglobulins in these sera were also able to deplete ${ }^{125}$ I-TSH binding activity. However, after receptor depletion, the one serum that did not inhibit ${ }^{125}$ I-TSH binding was associated with a significant increase in ${ }^{125} \mathrm{I}$ TSH binding.

All four sera specifically precipitated $80-100 \%$ of receptors identified by prelabeling with ${ }^{125} \mathrm{I}-\mathrm{TSH}$. The dilutions of sera that precipitated $50 \%$ of ${ }^{125}$ I-TSH-

Received for publication 8 June 1983 and in revised form 24 May 1984.

J. Clin. Invest.

(C) The American Society for Clinical Investigation, Inc. 0021-9738/84/09/1090/08 $\$ 1.00$

Volume 74, September 1984, 1090-1097 receptor complexes ranged from 1:150-1:20. Complexes were partially precipitated by high concentrations of control sera $(1: 20)$, but the relative potency of control sera was at least fourfold less than Graves' sera.

Immunoprecipitates of ${ }^{125}$ I-labeled thyroid membranes were analysed by sodium dodecyl sulfate-polyacrylamide gel electrophoresis and autoradiography to reveal Graves'-specific bands of reduced molecular weights of $100-110,000,80-90,000$, and 70-75,000. These bands were similar to those obtained from ${ }^{125} \mathrm{I}$ labeled thyroid membranes purified by TSH affinity chromatography. Thus, Graves' immunoglobulins: $(a)$ precipitate unoccupied and occupied TSH receptors, $(b)$ in one case, neither inhibit binding nor immunodeplete the unoccupied receptor but immunoprecipitate ${ }^{125}$ ITSH-receptor complexes, suggesting that binding of TSH may initiate an interaction between the binding site and a separate immunoreactive molecule, and (c) identify the molecular structure of Graves' autoantigens, putatively, the TSH receptor.

\section{Introduction}

Immunoglobulins that mimic thyrotropin (TSH), ${ }^{1}$ which are directed to sites on or close to the TSH receptor, are considered to play a pathogenetic role in Graves' hyperthyroidism (1-5). The evidence that these autoantibodies are anti-receptor antibodies derives from their ability to inhibit specific binding of TSH to particulate (6) or solubilized (7) thyroid membranes and to mimic the bioeffects of TSH in the whole organism (8), thyroid cells $(9,10)$, or thyroid membranes (11). Although it is over two decades since the discovery of these "thyroid stimulators" in human sera, relatively little information is

1. Abbreviations used in this paper: DTT, dithiothreitol; PEG, polyethylene glycol; SDS-PAGE, sodium dodecyl sulfate-polyacrylamide gel electrophoresis; Staph. protein A, formalin-fixed protein A-bearing Staphylococcus aureus of the Cowan I strain; TSH, thyrotropin. 
available on the molecular structure and function of the binding sites for Graves' immunoglobulins. Results obtained using different assays for "TSH receptor antibodies" show a lack of concordance within and between patients, indicating that the immunoglobulins are directed at a number of functionally-related determinants (12). It has also been found that immunoglobulins in normal sera may inhibit TSH binding (13-16). Such phenomena might be better understood if the molecular structures subserving TSH receptor antibody effects were defined.

By analogy with the studies of autoantibodies to acetylcholine (17) and insulin (18) receptors, it should be possible to address the question of the specificity of Graves' immunoglobulins and to elucidate the structure of the TSH receptor if indeed it is the autoantigen. Therefore, we decided to characterize the ability of Graves' and normal immunoglobulins to bind to and precipitate the solubilized TSH receptor, as a means of measuring such antibodies and defining the structure of Graves' autoantigens.

\section{Methods}

Highly purified bovine TSH (30 IU/mg) was from Dr. J. G. Pierce (University of California, Los Angeles) and partially purified bovine TSH (Thytropar, 3 IU/mg) from Armour Pharmaceutical Co. (Phoenix, AZ). Formalin-fixed protein A-bearing Staphylococcus aureus of the Cowan I strain (Staph. protein A) was purchased as a $10 \%$ suspension from the Commonwealth Serum Laboratories (Melbourne, Australia). Electrophoresis reagents were from Bio-Rad Laboratories (Richmond, CA) and activated Sepharose CH-4B from Pharmacia Fine Chemicals (Uppsala, Sweden). All other chemicals were from British Drug Houses (Port Fairy, Victoria, Australia) and were of analytical grade.

Sera were obtained, with consent, from four untreated female patients presenting with the classic clinical and biochemical features of Graves' disease and hyperthyroidism. Control sera were provided by apparently normal, age-matched laboratory staff. Six control sera were combined as a pooled control. Non-heat-inactivated sera were stored at $-20^{\circ} \mathrm{C}$. Anti-thyroglobulin and anti-microsomal antibodies were measured in sera using haemagglutination kits from Wellcome Laboratories (Beckenham, England).

The thyroid tissue used in the experiments described was obtained at operation from a patient undergoing thyroidectomy for a multinodular goiter.

Preparation of thyroid membranes. All procedures were performed at $4^{\circ} \mathrm{C}$. Thyroid tissue was washed in $10 \mathrm{mM}$ Tris-50 NaCl, pH 7.4 (Tris- $\mathrm{NaCl}$ ), and homogenized in 10 vol of Tris- $\mathrm{NaCl}$. The homogenate was centrifuged at $500 \mathrm{~g}$ for $15 \mathrm{~min}$, the pellet discarded, and the supernatant centrifuged at $10,000 \mathrm{~g}$ for $30 \mathrm{~min}$. The pellet was suspended in $\mathrm{Tris}-\mathrm{NaCl}$ containing $1 \%$ bovine serum albumin and stored at $-70^{\circ} \mathrm{C}$. The particulate membrane was solubilized by homogenization against glass in Tris- $\mathrm{NaCl}$ containing $1 \%(\mathrm{wt} / \mathrm{vol})$ Triton $\mathrm{X}-100$ and the protease inhibitors, leupeptin $(20 \mu \mathrm{g} / \mathrm{ml})$, Trasylol $(100 \mathrm{Kallikrein}$ inhibitory units $/ \mathrm{ml})$, and phenylmethylsulphonyl fluoride $\left(10^{-4} \mathrm{M}\right)$. After centrifugation at $100,000 \mathrm{~g}$ for $1 \mathrm{~h}$, the supernatant was stored at $-70^{\circ} \mathrm{C}$. Protein determinations were performed by the method of Bradford (19). Solubilized membranes were used at a concentration of $1 \mathrm{mg} / \mathrm{ml}$.
Radioiodination of TSH. Highly purified TSH was reacted with $\mathrm{Na}{ }^{125} \mathrm{I}$ in the presence of "Iodobeads" (Pierce Chemical Co., Rockford, IL) and iodinated to a specific activity of $50-100 \mu \mathrm{Ci} / \mu \mathrm{g}$. ${ }^{125} \mathrm{I}-\mathrm{TSH}$ was then receptor-purified as follows. $\sim 10^{8} \mathrm{cpm}{ }^{125} \mathrm{I}-\mathrm{TSH}$ was incubated for $1 \mathrm{~h}$ at $37^{\circ} \mathrm{C}$ with an excess of particulate thyroid membrane $(15$ $\mathrm{mg}$ ) in $5 \mathrm{ml}$ Tris- $\mathrm{NaCl}$. The membrane suspension was cooled to $4^{\circ} \mathrm{C}$, centrifuged at $15,000 \mathrm{~g}$ for $15 \mathrm{~min}$, and washed twice with cold Tris$\mathrm{NaCl}$. The pellet was then homogenized in $8 \mathrm{ml}$ of $2 \mathrm{M} \mathrm{NaCl}$ and the suspension centrifuged at $100,000 \mathrm{~g}$ at $4^{\circ} \mathrm{C}$ for $1 \mathrm{~h}$. The supernatant was applied to a 30-cm column of G-100 Sephadex (Pharmacia, South Seas, Pty. Ltd.) equilibrated in $\mathrm{Tris}-\mathrm{NaCl}$ and fractions corresponding to the peak of eluted ${ }^{125} \mathrm{I}-\mathrm{TSH}$ monomer were pooled and stored at $-70^{\circ} \mathrm{C}$. Radioiodinated TSH prepared by this method was used for at least $4 \mathrm{wk}$ without evidence of degradation in binding assays.

Effect of Graves' immunoglobulins on binding of ${ }^{125}$ I-TSH to solubilized thyroid membranes. The procedure used routinely in our laboratory to assay for TSH receptor antibodies is based on the TSH binding inhibitor immunoglobulin assay of Shewring and Rees-Smith (7). It employs conditions defined by Pekonen and Weintraub (20) for measuring specific high affinity TSH binding sites. Serum globulins are first precipitated with $15 \%$ (vol/vol) polyethylene glycol 4,000 (PEG) and reconstituted to the original volume of serum with Tris$\mathrm{NaCl}$. Solubilized thyroid membrane $(100 \mu \mathrm{g}$ protein; $100 \mu \mathrm{l})$ is then incubated for $1 \mathrm{~h}$ at $37^{\circ} \mathrm{C}$ with $100 \mu \mathrm{l}$ of ${ }^{125} \mathrm{I}$-TSH $(\sim 10,000 \mathrm{cpm})$ in Tris- $\mathrm{NaCl}$ buffer and $100 \mu \mathrm{l}$ of PEG-extracted normal or Graves' globulins. Nonspecific binding is measured by performing the reactions in the presence of an excess $\left(10^{-6} \mathrm{M}\right)$ of unlabeled TSH. The reaction mixtures are cooled to $4^{\circ} \mathrm{C}$ and $200 \mu \mathrm{l}$ of ice-cold Tris- $\mathrm{NaCl}$ added to each, followed by $500 \mu \mathrm{l}$ of a $30 \%$ solution of cold PEG in $1 \mathrm{M} \mathrm{NaCl}$. The reactants are mixed and centrifuged at $10,000 \mathrm{~g}$ for $45 \mathrm{~min}$ at $4^{\circ} \mathrm{C}$, the supernatants aspirated, and receptor-bound radioactivity in the pellets counted. Nonspecific binding is always $<10 \%$ of the total counts and precipitation by PEG of free ${ }^{125}$ I-TSH in Triton-buffer alone ("receptor blank") is of a similar magnitude. Specific binding of ${ }^{125} \mathrm{I}$-TSH in the presence of control sera ranges from 10 to $15 \%$ of total counts. Results are expressed according to the equation: 100 $\times(1-$ binding with Graves' globulins/binding with pooled control globulins).

Immunodepletion of TSH receptors. Solubilized thyroid membranes $(100 \mu \mathrm{l})$ were incubated for $16 \mathrm{~h}$ at $4^{\circ} \mathrm{C}$ with pooled control or individual Graves' sera diluted 1:20, 1:40, 1:80, 1:100, or 1:320. Staph. protein A suspension (10\%) was then added in a volume 50 -fold that of whole serum present and after a further incubation for $1 \mathrm{~h}$ at $4^{\circ} \mathrm{C}$, the suspensions were centrifuged and ${ }^{125} \mathrm{I}$-TSH binding studies performed on the supernatants, as described above.

Alternatively, individual control or Graves' sera $(50 \mu \mathrm{l})$ were incubated for $1 \mathrm{~h}$ at $4^{\circ} \mathrm{C}$ with $500 \mu \mathrm{l}$ of Staph. protein A suspension. The suspensions were then centrifuged, the supernatants discarded, and the pellets resuspended in solubilized thyroid membrane and incubated overnight at $4^{\circ} \mathrm{C}$. After centrifugation, the supernatants were assayed for ${ }^{125} \mathrm{I}$-TSH binding as described above.

Immunoprecipitation of TSH receptors. Solubilized thyroid membranes $(100 \mu \mathrm{l})$ were incubated with ${ }^{125} \mathrm{I}$-TSH $(\sim 10,000 \mathrm{cpm}$ in 100 $\mu$ l) for $1 \mathrm{~h}$ at $37^{\circ} \mathrm{C}$. Pooled control or individual Graves' sera were added in dilutions ranging from 1:20 to $1: 500$ and the incubation allowed to proceed for $16 \mathrm{~h}$ at $4^{\circ} \mathrm{C}$. A volume of Staph. protein A suspension 50-fold in excess of serum present was added, and after incubation for another $1 \mathrm{~h}$ at $4^{\circ} \mathrm{C}$, the suspensions were centrifuged at $10,000 \mathrm{~g}$ for $10 \mathrm{~min}$, the supernatants aspirated, and radioactivity in the pellets counted. In parallel experiments, ${ }^{125}$ I-TSH-receptor 
complexes present after incubation with serum were measured by precipitation with PEG, as described above. Experiments were also performed substituting Triton-buffer for solubilized thyroid membranes to exclude the presence of antibodies against ${ }^{125} \mathrm{I}$-TSH. Specific immune precipitation by Staph. protein A was expressed as a percentage of the specific PEG-precipitable counts. For both Staph. protein A and PEG, initial incubations were also performed in the presence of excess TSH $\left(10^{-6} \mathrm{M}\right)$ to determine nonspecific precipitation.

Immunoprecipitation of ${ }^{125}$ I-labeled thyroid antigens. Thyroid membranes were covalently labeled with ${ }^{125} \mathrm{I}(\mathrm{Na})$ using a lactoperoxidase-glucose oxidase system (21). $1 \mathrm{mg}$ of thyroid membrane was suspended in $1 \mathrm{ml}$ of $50 \mathrm{mM}$ Hepes buffer, $\mathrm{pH} \mathrm{7.4,} \mathrm{containing} 1 \mathrm{mM}$ glucose. $\mathrm{Na}{ }^{125} \mathrm{I}(1 \mathrm{mCi})$ was then added followed by lactoperoxidase (3.7 IU) and glucose oxidase (1.25 IU). After $5 \mathrm{~min}$ at $24^{\circ} \mathrm{C}$, the reaction was stopped by the addition of $9 \mathrm{ml}$ of cold Hepes buffer. After washing, the membranes were solubilized in $1 \% \mathrm{vol} / \mathrm{vol}$ Triton X-100 buffer containing protease inhibitors, as described above. Solubilized membranes had a specific activity of $\sim 300 \mu \mathrm{Ci} / 100 \mu \mathrm{g}$; $50-$ $60 \%$ of the radioactivity being precipitable with $5 \%$ trichloracetic acid. After being recycled through either control or TSH-Sepharose columns, as described below, aliquots $(100 \mu \mathrm{l})$ of labeled membranes containing at least $6 \times 10^{7}$ disintegrations per minute were incubated for $16 \mathrm{~h}$ at $4^{\circ} \mathrm{C}$ with a 1:100 dilution of serum from two control subjects and two patients (M.K., M.W.) with Graves' disease. Staph. protein A suspension was then added in a volume 50 -fold in excess of that of the serum present. After incubation at $4^{\circ} \mathrm{C}$ for at least $60 \mathrm{~min}$, immune pellets were recovered by centrifugation, washed in cold Tris- $\mathrm{NaCl}$ buffer, and resuspended in electrophoresis sample buffer $(0.0625 \mathrm{M}$ Tris, $2 \%$ sodium dodecyl sulfate [SDS], $100 \mathrm{mM}$ DTT). After heating at $56^{\circ} \mathrm{C}$ for $5 \mathrm{~min}$, aliquots were subjected to SDS-polyacrylamide gel electrophoresis (PAGE) using the system of Laemmli (22). Gels were dried and autoradiographed using Dupont Cronex, Lighting plus A-J, intensifying screens and Agfa x-ray film.

TSH-affinity chromatography of ${ }^{125}$ I-labeled thyroid membranes. Activated Sepharose CH-4B (1.5 g) was swollen in $1 \mathrm{mM} \mathrm{HCl}$ for $1 \mathrm{~h}$, washed, and resuspended in $0.1 \mathrm{M} \mathrm{NaHCO}_{3}, \mathrm{pH} 8.0$ (coupling buffer). TSH (6.6 mg 'Thytropar') was dialysed against coupling buffer overnight and then mixed with the gel suspension end-over-end for $1 \mathrm{~h}$ at $4^{\circ} \mathrm{C}$. The suspension was washed with coupling buffer followed by alternate washes at high $\mathrm{pH}(0.05 \mathrm{M}$ Tris $\mathrm{HCl}, 0.05 \mathrm{M} \mathrm{NaCl}, \mathrm{pH} 8.0)$ and low pH $(0.05 \mathrm{M} \mathrm{Na}$ acetate, $0.5 \mathrm{M} \mathrm{NaCl}, \mathrm{pH} 4.0)$. Then, the TSHSepharose conjugate was washed and stored in $\mathrm{Tris}-\mathrm{NaCl}$ buffer at $4^{\circ} \mathrm{C}$. The coupling efficiency determined by using ${ }^{125} \mathrm{I}$-TSH was estimated to be $95 \%$. A control column without the ligand was prepared in an identical fashion.

Solubilized ${ }^{125} \mathrm{I}$-labeled thyroid membrane $(2 \mathrm{ml}$ containing $2 \mathrm{mg}$ protein; $300 \mu \mathrm{Ci} / \mu \mathrm{g}$ ) was recycled four times over the TSH-Sepharose column at $22^{\circ} \mathrm{C}$. An equivalent amount of membrane was recycled over the control column. The unbound fractions from both columns were retained for immunoprecipitation as described above. The columns were washed with $20 \mathrm{ml}$ of Tris- $\mathrm{NaCl}$ buffer containing $0.05 \%$ Triton, and then, eluted with $2 \%$ SDS in $0.0625 \mathrm{M}$ Tris $\mathrm{HCl}, \mathrm{pH}$ 6.8. Fractions of $200 \mu \mathrm{l}$ were counted and aliquots of the peak fractions were analysed by SDS-PAGE under reducing ( $100 \mathrm{mM}$ DTT) conditions as described above.

\section{Results}

The levels of thyroid autoantibodies in the patient sera are shown in Table I. Three of the four sera (M.K., M.W., A.H.)
Table I. Thyroid Autoantibodies in Sera of Patients Studied

\begin{tabular}{llllll}
\hline & & & $\begin{array}{l}\text { TSH binding } \\
\text { inhibitory } \\
\text { immunoglobulins }\end{array}$ & $\begin{array}{l}\text { Anti-microsomal } \\
\text { antibodies }\end{array}$ & $\begin{array}{l}\text { Anti-thyroglobulin } \\
\text { antibodies }\end{array}$ \\
\hline M.K. & F & 40 & 18 & $1: 25,000$ & $1: 80$ \\
M.W. & F & 42 & 28 & $1: 400$ & negative \\
A.H. & F & 57 & 51 & $1: 15,000$ & negative \\
J.M. & F & 20 & -6 & $1: 15,000$ & negative
\end{tabular}

TSH binding inhibitory immunoglobulins were detected by measuring the effect of PEG-extracted plasma globulins on the binding of ${ }^{125}$ I-TSH to Triton-solubilized human thyroid membranes. Results are expressed as $100 \times(1-$ binding with Graves' globulins/binding with pooled control globulins), the normal range being -15 to +15 $(n=35$, coefficient of variation $<13 \%$ ). Anti-microsomal and antithyroglobulin antibodies were measured by standard hemagglutination techniques.

inhibited binding of ${ }^{125}$ I-TSH to solubilized receptors; the other serum (J.M.) had no significant effect on binding.

Immunodepletion of TSH receptors. After incubation of solubilized thyroid membranes with Graves' sera followed by the addition of Staph. protein A to precipitate IgG, specific ${ }^{125}$ I-TSH binding activity was decreased between 30 and $80 \%$ for the three binding inhibitory sera (M.K., M.W., A.H.), but unexpectedly, was increased to $200 \%$ of control for the serum (J.M.) that did not alter binding directly (Fig. 1). In the presence of pooled control serum, ${ }^{125} \mathrm{I}$-TSH binding was always within $15 \%$ of buffer control. Depletion of ${ }^{125} \mathrm{I}$-TSH binding activity using Graves' sera was not associated with any change in the specific binding of ${ }^{125}$ I-insulin or ${ }^{125} \mathrm{I}$-epidermal growth factor to their receptors in solubilized thyroid membranes (data not shown).

Although Staph. protein A had been added in excess to priccipitate all IgG present, to confirm that the changes in binding with Graves' sera were due to immunodepletion of TSH binding sites and/or associated molecules, as opposed to an effect of residual IgG, experiments were also carried out using preformed complexes between Staph. protein A and immunoglobulins. By this method, the three sera that had inhibited ${ }^{125} \mathrm{I}-\mathrm{TSH}$ binding directly immunodepleted TSH binding activity between 30 and $50 \%$ compared with control sera (Fig. 2). Again, serum J.M. (without a direct effect on ${ }^{125}$ I-TSH binding) resulted in a $30 \%$ increase in binding activity after this immunodepletion procedure (Fig. 2).

Immunoprecipitation of TSH receptors. All four Graves' sera, at dilutions up to $1: 500$, were able to specifically immunoprecipitate ${ }^{125} \mathrm{I}$-TSH-receptor complexes (Fig. 3). No serum resulted in the precipitation of ${ }^{125} \mathrm{I}-\mathrm{TSH}$ in the absence of solubilized thyroid membrane. Dilutions of sera able to immunoprecipitate $50 \%$ of PEG-precipitable complexes ranged from 1:150 to $1: 20$. Over $80 \%$ of PEG-precipitable complexes could be immunoprecipitated using high concentrations of all Graves' sera (1:20). The same high concentration of pooled 


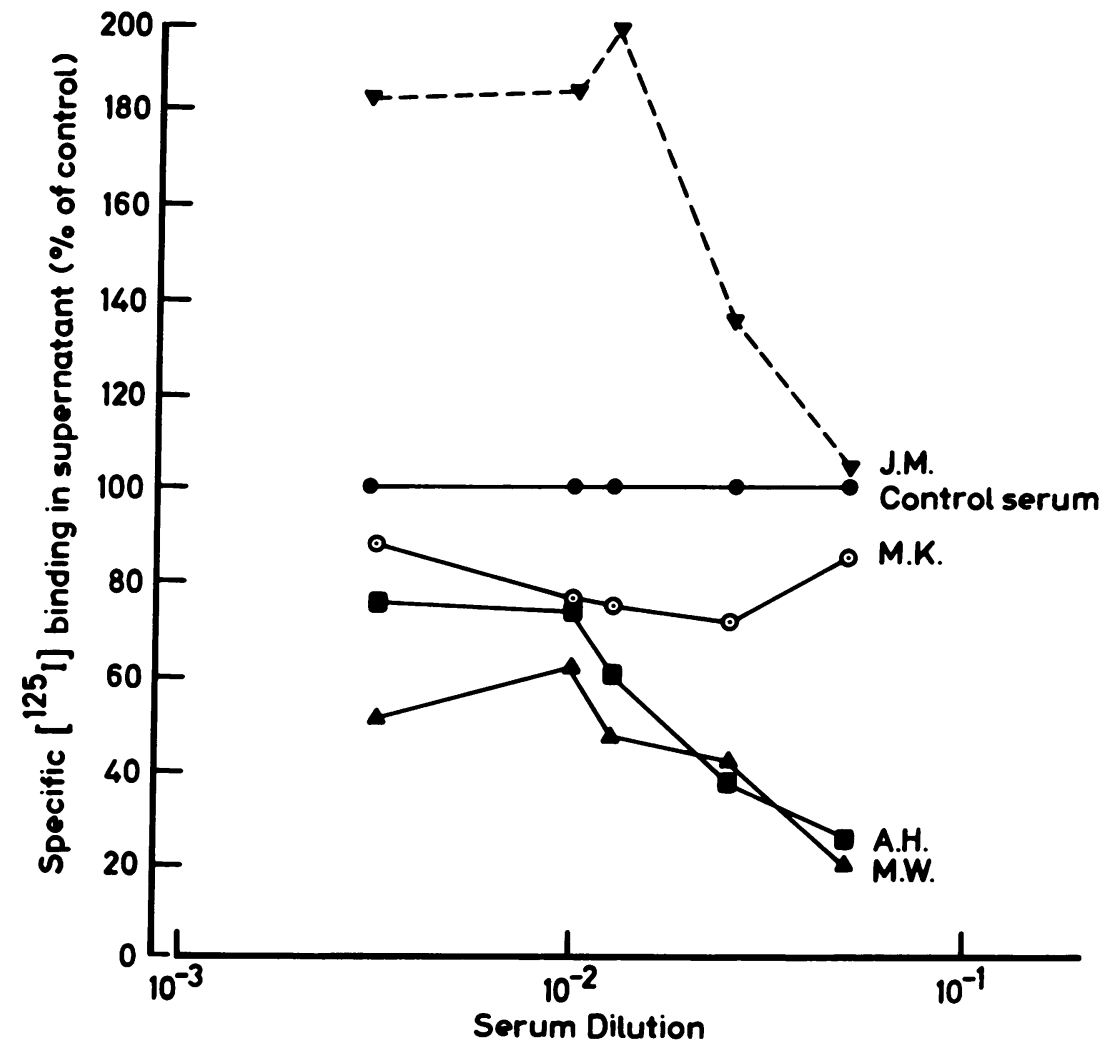

Figure 1. ${ }^{125} \mathrm{I}-\mathrm{TSH}$ binding activity in solubilized thyroid membranes after immunodepletion using Graves' sera. Solubilized thyroid membrane was incubated overnight at $4^{\circ} \mathrm{C}$ with dilutions of pooled control or individual Graves' sera, followed for a further $1 \mathrm{~h}$ with an excess of Staph. protein A. After precipitation of immune complexes, ${ }^{125} \mathrm{I}$-TSH binding activity in the supernatants was measured in triplicate over $1 \mathrm{~h}$ at $37^{\circ} \mathrm{C}$, as described in Methods. Each point is the mean of three experiments, reproducible with a coefficient of variation $<13 \%$. control serum also precipitated a significant amount of complex. However, the relative potency of Graves' sera, based on the dilutions that precipitate the same percent of complexes as

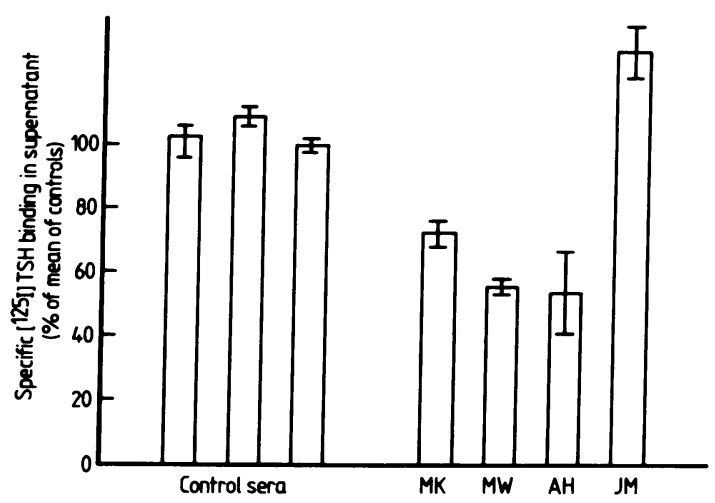

Figure 2. Immunodepletion of ${ }^{125} \mathrm{I}$-TSH binding activity from solubilized thyroid membranes by preformed Graves' IgG-Staph. A complexes. Individual control or Graves' sera were incubated for $1 \mathrm{~h}$ at $4^{\circ} \mathrm{C}$ with Staph. protein A. Washed IgG-Staph. protein A complexes were then incubated overnight at $4^{\circ} \mathrm{C}$ with solubilized thyroid membrane. After precipitation of the complexes, ${ }^{125} \mathrm{I}$-TSH binding activity in the supernatants was measured in triplicate over $1 \mathrm{~h}$ at $37^{\circ} \mathrm{C}$, as described in Methods. Each point is the mean $\pm \mathrm{SD}$ of three experiments. maximum control serum (1:20), was $4-10$-fold higher. It is noteworthy that Graves' serum J.M. which was negative in the ${ }^{125}$ I-TSH binding assay was able to immunoprecipitate all ${ }^{125}$ I-TSH labeled receptors. Neither Graves' nor control sera precipitated complexes between ${ }^{125} \mathrm{I}$-insulin and its receptor from solubilized thyroid membranes (data not shown). Immunoprecipitation could also be effected by using preformed complexes between Staph. protein A and immunoglobulins. However, starting with the same amounts of sera and Staph. protein A suspension, precipitation using Graves' sera was not quite as efficient; maximum precipitation of ${ }^{125} \mathrm{I}$-TSH-receptor complexes was $\sim 60 \%$. Under these conditions, control sera at a dilution equivalent to $1: 20$ precipitated $<10 \%$ of ${ }^{125}$ I-TSHreceptor complexes.

SDS-PAGE analysis of ${ }^{125}$ I-labeled thyroid antigens. Graves' sera (M.K., M.W.) specifically precipitated thyroid antigens with reduced molecular weights $\left(M_{\mathrm{r}}\right.$ 's) of $100-110,000,80$ 90,000 , and $70-75,000$ (ranges of five experiments) from ${ }^{125} \mathrm{I}$ labeled membranes before or after recycling of membranes over the control Sepharose column. Serum M.K. also precipitated two larger species with $M_{\mathrm{r}}$ 's of $\sim 300,000$ and 265,000 (Fig. $4 a$ ). These bands were not seen with either of the two control sera tested at the same dilution $(1: 100)$. The band of $M_{\mathrm{r}} 50-60,000$ in all lanes is radioactivity commonly seen to be associated in immune precipitates with the heavy chain of $\mathrm{IgG}$, and assumed to be nonspecific. The Graves'-specific 


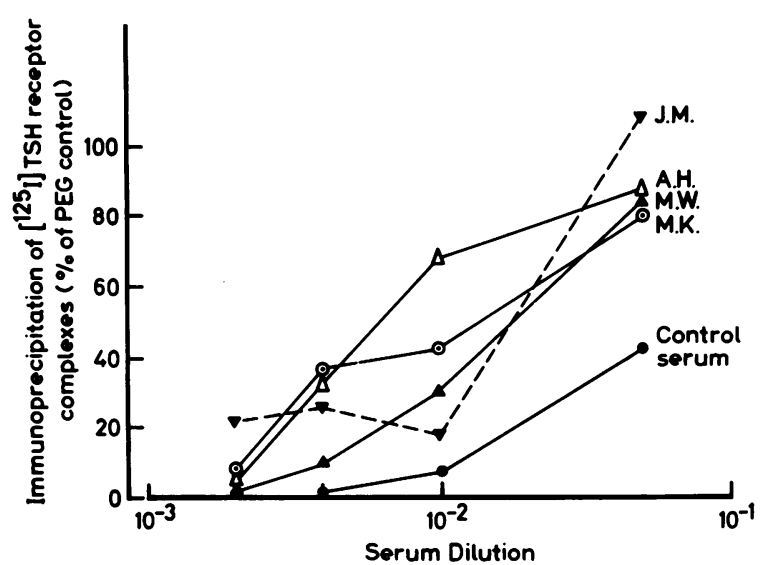

Figure 3. Immunoprecipitation of ${ }^{125} \mathrm{I}-\mathrm{TSH}$ complexes from solubilized thyroid membranes. Solubilized thyroid membrane was incubated with ${ }^{125} \mathrm{I}-\mathrm{TSH}$ for $1 \mathrm{~h}$ at $37^{\circ} \mathrm{C}$. Dilutions of pooled control or individual Graves' sera were added in duplicate, and incubations allowed to proceed overnight at $4^{\circ} \mathrm{C}$. Staph. protein A was then added for another $1 \mathrm{~h}$. The immune complexes were precipitated, washed, and counted. The results are expressed as a percentage of ${ }^{125}$ I-TSH-receptor complexes specifically precipitated by PEG after prior incubation with serum. Each point is the mean of three experiments, reproducible with a coefficient of variation of $<10 \%$. bands were unaltered when labeled membranes were incubated for $60 \mathrm{~min}$ at $37^{\circ} \mathrm{C}$ with an excess of TSH $\left(10^{-6} \mathrm{M}\right)$ prior to immunoprecipitation (not shown). However, a marked decrease in the intensity of the Graves'-specific bands was observed when immunoprecipitation was performed on labeled membranes that had been recycled over the TSH-Sepharose column (Fig. $4 b$ ).

SDS-PAGE analysis of TSH-affinity purified ${ }^{125}$ I-labeled thyroid membrane proteins. Purification of ${ }^{125}$ I-labeled thyroid membranes by SDS elution from a TSH-Sepharose column yielded specific bands corresponding to reduced $M_{\mathrm{r}}$ 's of 100 $110,000,80-90,000$ and $60-70,000$ (ranges of two experiments). No radioactive bands were eluted from the control column (Fig. 5).

\section{Discussion}

These results provide further evidence that TSH receptor antibodies bind to TSH binding sites and/or closely-associated molecules. They also demonstrate the feasibility of measuring such antibodies by precipitation of solubilized TSH receptors and the potential use of Graves' immunoglobulins as probes of the structure of thyroid antigens. Such applications of receptor autoantibodies have been previously described in a

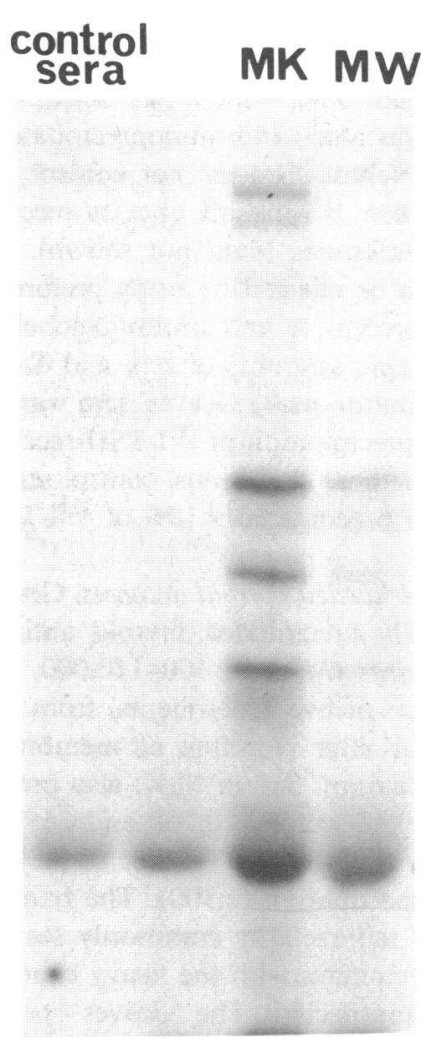

b

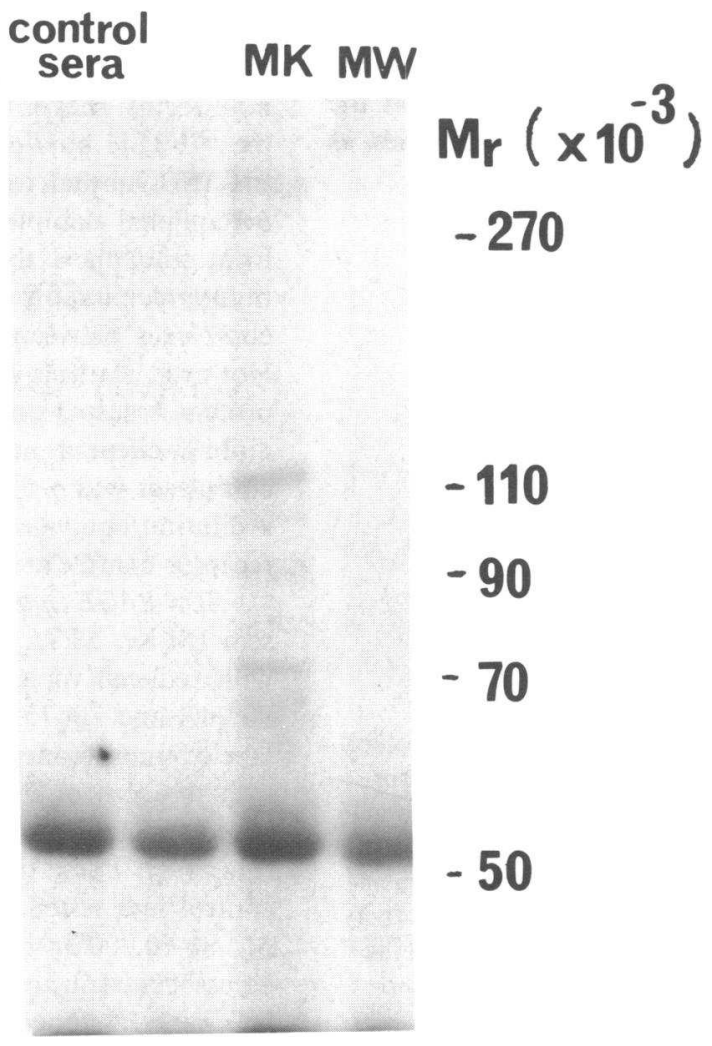

Figure 4. SDS-PAGE and autoradiography of ${ }^{125}$ I-labeled thyroid membrane antigens immunoprecipitated using two Graves' sera (M.K., M.W.) and two control sera from labeled membranes recycled over $(a)$ a control Sepharose column and $(b)$ a TSH-Sepharose column. Electrophoresis was performed in $7.5 \%$ polyacrylamide gels under reducing conditions (100 mM DTT) using the Laemmli system (22). 


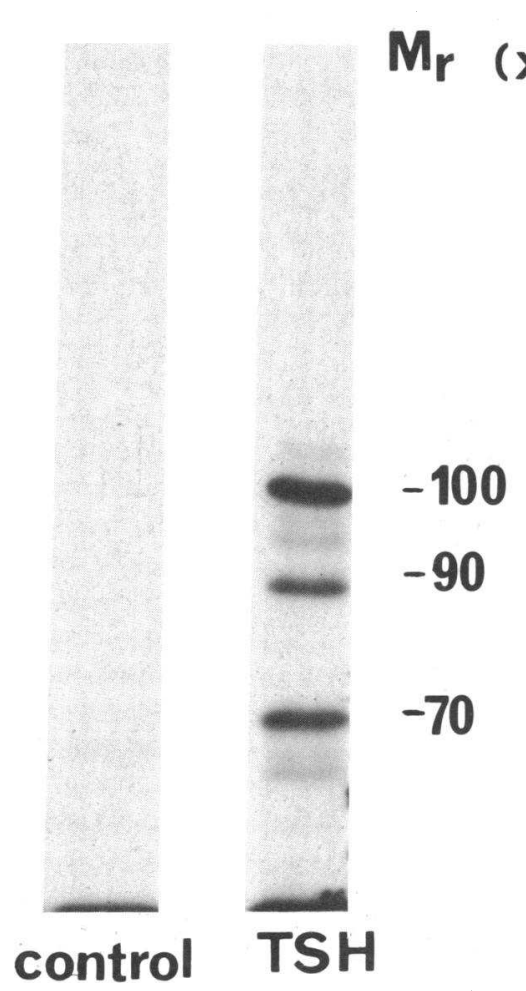

Figure 5. SDS-PAGE and autoradiography of ${ }^{125}$ I-labeled thyroid membrane proteins eluted from a control Sepharose column and a TSH-Sepharose column. Electrophoresis was performed under reducing conditions as described above.

detail only for autoantibodies to receptors for acetylcholine (17) and insulin (18).

Immunoprecipitation of TSH receptors was attempted both in the absence ("receptor depletion") and in the presence ("receptor precipitation") of bound ${ }^{125}$ I-TSH. These alternate approaches were taken to investigate the possibility that occupancy, even by tracer concentrations of ${ }^{125} \mathrm{I}-\mathrm{TSH}$, might prevent immunoprecipitation either because of direct competition with antibodies or by an allosteric mechanism. Even if the receptor was univalent and occupied by hormone, it seemed likely to us that polyclonal Graves' immunoglobulin would precipitate the complex. Nevertheless, Rickards et al. (23) failed in attempts to immunoprecipitate complexes between receptor and TSH, an outcome which led them to conclude that Graves' immunoglobulins and TSH interact at the same site. Our findings clearly demonstrate that Graves' immunoglobulins lead to the precipitation of either unoccupied or occupied TSH receptors. All four Graves' sera immunoprecipitated at least $80 \%$ of ${ }^{125} \mathrm{I}$-TSH-receptor complexes and the titers for immunoprecipitation of complexes were no less than for immunodepletion of unoccupied binding sites. Therefore, we conclude that some Graves' immunoglobulins precipitate the TSH receptor by binding to determinants outside of the
TSH binding site. Certainly this appears to be the case for the serum of patient J.M. which did not inhibit binding but did precipitate the receptor. On the other hand, if some Graves' immunoglobulins interacted with the TSH binding site in a mutually exclusive fashion, then immunoprecipitation could also result if the solubilized receptor was multivalent and only partially occupied after being labeled with tracer amounts of ${ }^{125}$ I-TSH. This question could be studied by quantifying the relationship between receptor occupancy and immunoprecipitation, preferably by using methods (e.g., chemical crosslinking, photoaffinity labeling) that lead to the irreversible binding of hormone.

Our findings amplify and extend a recent report by de Bruin and van der Heide (24) which showed that Graves' immunoglobulins interact directly with the TSH receptor and lead to its immunoprecipitation. These investigators were able to immunoprecipitate the TSH-receptor complex even when saturating amounts of hormone were used, but only a small percent of the available complexes were specifically precipitated. The reason for this very low degree of specific immunoprecipitation is probably methodological since using different incubation conditions, we were able to quantitatively precipitate either unoccupied or occupied receptors. Furthermore, studies in progress show that similar results to those reported here are obtained using thyroid tissue from several different donors. Our findings indicate that immunoprecipitation is a sensitive and reproducible method for measuring TSH receptor antibodies in contrast to standard in vitro methods, e.g., binding inhibition, which employ high concentrations of serum, typically $>1: 10$. However, the increased sensitivity of immunoprecipitation could be off-set by a decrease in clinical specificity since immunoprecipitation would in theory detect antibodies directed at many determinants on the receptor, not only, for example, those involved in TSH binding or in mediating clinically relevant effects $(12,25)$. Therefore, the clinical value of the immunoprecipitation assay will need to be evaluated by further correlative studies.

As observed by others using particulate thyroid membranes (13-16), we found that control immunoglobulins from subjects without thyroid disease bound to the solubilized TSH receptor. The effect of high concentrations of control immunoglobulins was readily observed in the binding inhibition assay and with the precipitation of ${ }^{125} \mathrm{I}$-TSH-receptor complexes, but under the conditions used, was minimal with depletion of receptors. This difference between immunoprecipitation and immunodepletion may be more apparent than real since Staph. protein A has a higher avidity for immune complexes (26). Whether control immunoglobulins react with the receptor via their $\mathrm{F}(\mathrm{ab})_{2}$ combining sites in a manner qualitatively indistinguishable from Graves' immunoglobulins remains unclear. The possibility that low levels of receptor autoantibodies in clinically normal subjects have physiological significance cannot be excluded. However, given the conditions in vitro for detecting TSH receptor antibodies by immunoprecipitation, a clear difference is apparent between the potency of Graves' and 
control immunoglobulins. The ability to dilute out the effect of control serum is one of the advantages of this technique.

That J.M.'s serum immunoprecipitated the TSH-receptor complex but did not inhibit TSH binding demonstrates the uniqueness of immunoprecipitation and supports the concept that Graves' immunoglobulins can be directed against determinants outside of the TSH binding site. J.M.'s serum was able to precipitate the ${ }^{125} \mathrm{I}$-TSH-receptor complex but not immunodeplete the unoccupied receptor, suggesting that immunoglobulins in J.M.'s serum are not directed against the binding molecule but against a separate molecule which interacts with the binding site when the latter is occupied by TSH. Control experiments showed that J.M.'s serum did not contain antibodies to TSH itself. Since ${ }^{125}$ I-TSH binding was increased after immunodepletion, the separate target molecule for immunoglobulins in J.M.'s serum might exert an inhibitory influence on the expression or affinity of the TSH binding site in manner analogous to the guanosine triphosphate (GTP) binding protein involved in coupling and affinity regulation of beta adrenergic and other receptors (27).

Purification and structural characterization of the TSH receptor has been attempted mainly by the use of TSH affinity chromatography, but there is a lack of consensus regarding the molecular size of the TSH binding species, with estimates ranging from 15,000 to $500,000(23,28-30)$. There are no full reports characterizing the molecular species recognized by Graves' immunoglobulins. After immunoprecipitation of ${ }^{125} \mathrm{I}$ labeled thyroid membranes and analysis by SDS-PAGE and autoradiography, under reducing conditions, we have reproducibly isolated Graves'-specific bands of $M_{\mathrm{r}} 100-110,000,80$ 90,000 , and 70-75,000. The example shown in Fig. 4 also demonstrates the isolation of two higher $M_{\mathrm{r}}$ bands by using serum from patient M.K. These bands could be higher $M_{\mathrm{r}}$ or unreduced forms of the TSH receptor, or alternatively, might represent subunit species of thyroglobulin since they are seen with sera (e.g., M.K.) positive for thyroglobulin antibodies but not with sera (e.g., M.W.) negative for thyroglobulins antibodies. The bands seen at 50-60,000 are usually considered to represent nonspecific radioactivity associated with the heavy chain of IgG which resolves at this position in the gel. The increased radioactivity in this region using Graves' sera is also associated with a greater amount of Coomassie-stained IgG heavy chain (not shown). Immunoglobulins in serum from patients M.K. and M.W. inhibited TSH binding and immunodepleted TSH binding activity from solubilized human thyroid membranes, suggesting that the Graves'-specific bands could represent subunit components of the TSH receptor. It is noteworthy that two of these bands are similar in size to those of molecular weight of 88,000 and 66,000 isolated by Koizumi et al. (30) using TSH affinity chromatography. Kohn et al. (31) have recently reported a 50-55,000 species as well as $18-23,000$ species precipitated by a monoclonal antibody to the thyroid TSH receptor. Smaller molecular weight species may have been precipitated by the autoantibodies but would not have been resolved by our gel system.
Purification of ${ }^{125} \mathrm{I}$-labeled thyroid membranes by elution from the TSH affinity column yielded specific proteins of $M_{\mathrm{r}}$ 100-110,000, 80-90,000, and 60-70,000. The two higher $M_{\mathrm{r}}$ proteins are identical in size to those precipitated using Graves' sera; the lower $M_{\mathrm{r}}$ protein may or may not be significantly different from the $M_{\mathrm{r}}$ 70-75,000 species precipitated using Graves' sera, given the imprecision of $M_{\mathrm{r}}$ estimations in gels. Moreover, there was a marked decrease in the appearance of all three Graves'-specific bands when ${ }^{125}$ I-labeled membranes were first cycled over the TSH affinity column. These findings strongly suggest that immunoglobulins in these Graves' sera bind to the subunit components of the TSH receptor or closelyassociated molecules. The failure to block immunoprecipitation of these proteins by preincubation of solubilized membranes with excess TSH confirms that Graves' immunoglobulins also recognize determinants outside of the TSH binding site(s) in these proteins.

Our findings demonstrate the feasibility of immunoprecipitation as an assay for TSH receptor antibodies and the usefulness of Graves' immunoglobulins as probes of thyroid autoantigen structure. They support the view that the TSH receptor is the major antigenic target of Graves' immunoglobulins.

\section{References}

1. Major, P. W., and D. S. Munro. 1962. Observations on the stimulation of thyroid function in mice by the injection of serum from normal subjects and from patients with thyroid disorders. Clin. Sci. (Lond.). 23:463-475.

2. Kriss, J. P., V. Pleshakov, and J. R. Chien. 1964. Isolation and identification of the long acting thyroid stimulator and its relation to hyperthyroid and circumscribed pre-tibial myxedema. J. Clin. Endocrinol. Metab. 24:1005-28.

3. Manley, S. W., J. R. Bourke, and R. J. Hawker. 1974. The thyrotropin receptor in guinea pig thyroid homogenate: interaction with the long acting thyroid stimulator. J. Endocrinol. 61:437-445.

4. McKenzie, J. M., and M. Zakarija. 1976. A reconsideration of the thyroid stimulating immunoglobulin as the cause of hyperthyroidism in Graves' disease. J. Clin. Endocrinol. Metab. 42:778-784.

5. McKenzie, J. M., and M. Zakarija. 1978. The pathogenesis of neonatal Graves' disease. J. Endocrinol. Invest. 2:183-189.

6. Smith, B. R., and R. Hall. 1974. Thyroid stimulating immunoglobulins in Graves' disease. Lancet II:427-431.

7. Shewring, G., and B. Rees-Smith. 1982. An improved radioreceptor assay for TSH receptor antibodies. Clin. Endocrinol. 17:409417.

8. Kendall-Taylor, P. 1975. LATS and human specific thyroid stimulator: their relation to Graves' disease. J. Clin. Endocrinol. Metab. 4:319-339.

9. Etienne-Decerf, J., and R. J. Winand. 1981. A sensitive technique for determination of thyroid-stimulating immunoglobulin (TSI) in unfractionated serum. Clin. Endocrinol. 14:83-91.

10. Hinds, W. E., N. Tabai, B. Rapoport, S. Filetti, and O. H. Clark. 1981. Thyroid stimulating immunoglobulin bioassay using cultured human thyroid cells. J. Clin. Endocrinol. Metab. 52:12041210. 
11. Karlsson, F. A., P. A. Dahlberg, and O. Walinder. 1981. Activation of membrane-bound adenyl cyclase by thyroid stimulating antibodies. Acta Endocrinol. 97:60-66.

12. Manley, S. W. W., A. Knight, and D. D. Adams. 1982. The thyrotrophin receptor. Springer Semin. Immunopathol. 5(4):413-431.

13. Beall, G. N., I. J. Chopra, D. H. Solomon, and S. R. Kruger. 1978. Serum protein inhibition of thyrotropin binding to human thyroid tissue. J. Clin. Endocrinol. Metab. 47:967-972.

14. McKenzie, J. M., M. Zakarija, and A. Sato. 1978. Humoral immunity in Graves' disease. J. Clin. Endocrinol. Metab. 7:31-45.

15. Kleinmann, R. E., L. E. Braverman, A. G. Vagenakis, R. W. Butcher, and R. B. Clark. 1980. A new method for measurement of human thyroid-stimulating immunoglobulin. J. Lab. Clin. Med. 95:581583.

16. Brown, R. S., L. P. Kertiles, and S. Reichlin. 1983. Partial purification and characterization of thyrotropin binding inhibitory immunoglobulins from normal human plasma. J. Clin. Endocrinol. Metab. 56:156-163.

17. Lindstrom, J. 1976. Immunological studies of acetylcholine receptors. J. Supramol. Struct. 4:389-403.

18. Harrison, L. C., and C. R. Kahn. 1980. Autoantibodies to the insulin receptors: clinical significance and experimental applications. Prog. Clin. Immunol. 4:107-125.

19. Bradford, M. M. 1976. A rapid, and sensitive method for the quantitation of microgram quantities of protein using the principle of protein dye binding. Anal. Biochem. 72:248-254.

20. Pekonen, F., and B. D. Weintraub. 1979. Thyrotropin receptors on bovine thyroid membranes: two types with different affinities and specificities. Endocrinology. 105:352-359.

21. Hubbard, A. L., and Z. A. Cohn. 1972. The enzymatic iodination of the red cell membrane. J. Cell. Biol. 55:390-405.

22. Laemmli, U. K. 1970 . Cleavage of structural proteins during assembly of the head of bacteriophage $\mathrm{T}_{4}$. Nature (Lond.). 227:680683.

23. Rickards, C., P. Buckland, B. R. Smith, and R. Hall. 1981. The interaction of Graves' IgG with the thyrotropin receptors. FEBS (Fed. Eur. Biochem. Soc.) Lett. 127:17-21.

24. de Bruin, T. W. A., and D. van der Heide. 1983. Antithyrotrophin receptors antibodies in Graves' disease as demonstrated directly by immunoprecipitation assay. Acta Endocrinol. 102:49-56.

25. Valente, W. A., P. Vitti, Z. Yavin, E. Yavin, C. M. Rotella, E. F. Grollman, R. S. Toccafondi, and L. D. Kohn. 1982. Monoclonal antibodies to the thyrotropin receptor: stimulating and blocking antibodies derived from the lymphocytes of patients with Graves' disease. Proc. Natl. Acad. Sci. USA. 79:6680-6684.

26. Kessler, S. W. 1975. Rapid isolation of antigens from cells with a Staphylococcal protein A-antibody absorbent: parameters of the interaction of antibody-antigen complexes with protein A. J. Immunol. 115:1617-1624.

27. Rodbell, M. 1980. The role of hormone receptors and GTPregulatory proteins in membrane transduction. Nature (Lond.). 284:1722.

28. Czarnocka, B., J. Nauman, G. Adler, and K. Kielczynski. 1979. Solubilization and partial characterization of thyroid membrane TSH binding proteins. Acta Endocrinol. 92:512-521.

29. Iida, Y., J. Konishi, K. Kasagi, K. Ikekubo, K. Kuma, and K. Torizuka. 1981. Characterization of Triton-solubilized TSH receptors from human thyroid plasma membranes. Acta Endocrinol. 98:50-56.

30. Koizumi, Y., M. Zakarija, and J. M. McKenzie. 1982. Solubilization, purification and partial characterization of thyrotropin receptor from bovine and human thyroid glands. Endocrinology. 110:1381-1391.

31. Kohn, L. D., W. A. Valente, P. Lacetti, J. L. Cohen, S. M. Aloj, and E. F. Grollman. 1983. Multicomponent structure of the thyrotropin receptor: relationship to Graves' disease. Life Sci. 32:1530. 